\title{
ANALYSIS OF FACTORS AFFECTING THE EXAMINATION VISIT OF PATIENTS WITH DRUGS RESISTANT TUBERCULOSIS IN MEDAN CITY, NORTH SUMATERA
}

\author{
Mayang Sari Ayu'), Marlon Sihombing3), Heru Santosa'), \\ Erna Mutiara'), Rahmadani Sitepu' ${ }^{1)}$ \\ 1)Department of Public Health, Faculty of Medicine, \\ Universitas Islam Sumatera Utara \\ 2)Faculty of Public Health, Universitas Sumatera Utara \\ 3)Department of Social and Political Sciences, Universitas Sumatera Utara
}

\begin{abstract}
Background: Tuberculosis-resistant drugs are caused by many factors, including lack of roles by health personnel, drug management in public health centers, bacterial microbiology, and patient compliance. WHO in Global Tuberculosis Report 2015 reported that Indonesia was globally ranked 8th out of 27 countries. It was estimated that $1.9 \%$ of new cases and $12 \%$ of cases with retreatment, only $66 \%$ were successful second-line treatment of anti-tuberculosis drugs. This study aimed to analyze factors affecting the examination visit of patients with drugs resistant tuberculosis in Medan city, North Sumatera.
\end{abstract}

Subjects and Method: This was an analytical observational study with a cross sectional design. The study was conducted at 12 community health centers, Medan City, North Sumatera. A sample of 66 TB patients with multi-drug resistant tuberculosis was selected for this study by purposive sampling. The independent variables were health personnel role, patient behavior, and health service. The dependent variable was the examination visit of patients with drugresistant tuberculosis. The data were collected by questionnaire and medical records. The data were analyzed by bivariate analysis and a multiple logistic regression.

Results: The bivariate analysis showed that the examination visit of patients with drug-resistant tuberculosis was affected by health personnel role (OR=9.00; 95\% $\mathrm{CI}=1.07$ to $76.02 ; \mathrm{p}=0.019)$, patients behavior $(\mathrm{OR}=3.67,95 \% \mathrm{CI}=0.32$ to 42.12, $\mathrm{p}=0.268)$, health service $(\mathrm{OR}=0.32,95 \% \mathrm{CI}=0.01$ to $0.13, \mathrm{p}<0.001)$. A multiple logistic regression did not show statistical significant relationship between the study variables.

Conclusion: Examination visit of patients with drug-resistant tuberculosis is affected by health personnel role, health behavior, and health service.

Keywords: multi-drug resistance tuberculosis, examination visit, community health center

\section{Correspondence:}

Mayang Sari Ayu. Faculty of Public Health, Universitas Sumatera Utara, Medan, North Sumatera, Indonesia. E-mail: dr_mayang@yahoo.co.id.

Mobile: 08126554136. 